Published in final edited form as:

Thorac Surg Clin. 2019 May ; 29(2): 123-131. doi:10.1016/j.thorsurg.2018.12.001.

\title{
THE ROLE OF THE THYMUS IN THE IMMUNE RESPONSE
}

PUSPA THAPA, PH.D. [POSTDOCTORAL RESEARCH SCIENTIST] and COLUMBIA CENTER FOR TRANSLATIONAL IMMUNOLOGY, COLUMBIA UNIVERSITY MEDICAL CENTER, NEW YORK, NY USA

\section{DONNA L. FARBER, PH.D. [PROFESSOR OF SURGICAL SCIENCES] DEPARTMENT OF SURGERY, COLUMBIA UNIVERSITY MEDICAL CENTER, NEW YORK, NY USA}

\begin{abstract}
THE THYMUS IS A PRIMARY LYMPHOID ORGAN ESSENTIAL FOR THE DEVELOPMENT OF T LYMPHOCYTES WHICH ORCHESTRATE ADAPTIVE IMMUNE RESPONSES. T CELL DEVELOPMENT IN THE THYMUS IS SPATIALLY REGUALTED; KEY CHECKPOINTS IN T CELL MATURATION AND SELECTION OCCUR IN CORTICAL AND MEDULLARY REGIONS TO ELIMINATE SELF-REACTIVE T CELLS, ESTABLISH CENTRAL TOLERANCE, AND EXPORT NAIVE T CELLS TO THE PERIPHERY WITH THE POTENTIAL TO RECOGNIZE DIVERSE PATHOGENS. THYMIC OUTPUT IS ALSO TEMPORALLY REGULATED DUE TO AGE-RELATED INVOLUTION OF THE THYMUS ACCOMPANIED BY LOSS OF EPITHELIAL CELLS. IN THIS REVIEW, WE DISCUSS THE STRUCTURAL AND AGE-RELATED CONTROL OF THYMUS FUNCTION IN HUMANS.
\end{abstract}

\section{Keywords \\ T LYMPHOCYTES; EPITHELIAL CELLS; IMMUNOSENESCENCE; T CELL DEVELOPMENT}

\section{Introduction}

The thymus is an organ that is critically important to the immune system which serves as the body's defense mechanism providing surveillance and protection against diverse pathogens, tumors, antigens and mediators of tissue damage. The immune system comprises a complex network of cellular and molecular components subdivided into thymus-independent (innate)

COLUMBIA CENTER FOR TRANSLATIONAL IMMUNOLOGY, COLUMBIA UNIVERSITY MEDICAL CENTER, $650 \mathrm{~W}$ 168TH STREET, BB1501, NEW YORK, NY 10032; PT2485@CUMC.COLUMBIA.EDU COLUMBIA CENTER FOR TRANSLATIONAL IMMUNOLOGY, COLUMBIA UNIVERSITY MEDICAL CENTER, $650 \mathrm{~W}$ 168TH STREET, BB1501, NEW YORK, NY 10032; DF2396@CUMC.COLUMBIA.EDU DISCLOSURE STATEMENT: THE AUTHORS HAVE NOTHING TO DISCLOSE

Disclosure of any relationship with a commercial company that has a direct financial interest in subject matter or materials discussed in article or with a company making a competing product

Publisher's Disclaimer: This is a PDF file of an unedited manuscript that has been accepted for publication. As a service to our customers we are providing this early version of the manuscript. The manuscript will undergo copyediting, typesetting, and review of the resulting proof before it is published in its final citable form. Please note that during the production process errors may be discovered which could affect the content, and all legal disclaimers that apply to the journal pertain. 
and thymus-dependent (adaptive) arms which function synergistically in all immune responses. Innate immunity constitutes the first line of defense and is mediated by innate immune cells such as tissue macrophages, dendritic cells (DC), and granulocytes which elicit their effector function within minutes to hours following antigen exposure. Innate cells become activated via germ-line encoded pattern recognition receptors (PRR), including tolllike receptors (TLR) and NOD-like receptors (NLRP) which recognize invariant features of pathogens (pathogen-associate molecular patterns or PAMPS) and tissue damage (For a review, see ${ }^{1}$ ). Once activated, innate cells such as macrophages and neutrophils can effectively clear antigens via phagocytosis. Other types of innate cells, such as DC take up and process antigens, resulting in expression of antigenic epitopes in conjunction with their major histocompatibility complex (MHC) or HLA molecules. These DC can then serve as antigen-presenting cells (APC) for the priming of the adaptive immune system. In this way, the early innate response is coupled to, and facilitates adaptive immunity.

The adaptive immune system consists of $\mathrm{T}$ and $\mathrm{B}$ lymphocytes which express specific antigen recognition receptors and develop highly specialized effector functions with the ability to form long-term immunological memory. Both B cells and T cells develop from bone marrow-derived progenitors; while mature B cells are exported to the periphery directly from the bone marrow, $\mathrm{T}$ cell development, maturation and export require critical differentiation steps to occur in the thymus. Thymus-dependent $\mathrm{T}$ cell differentiation processes include expression of an antigen-specific cell surface T cell receptor (TCR) through recombination of germline-encoded gene segments, and thymic "education" involving negative selection of potentially self-reactive $\mathrm{T}$ cells and positive selection of $\mathrm{T}$ cells with the capacity to recognize antigens encountered in the periphery. These important thymic processes ensure that $\mathrm{T}$ cells can recognize antigens in the context of self-MHC, but do not elicit self-reactivity.

One exported from the thymus, the resultant "naïve" $\mathrm{T}$ cells populate multiple secondary lymphoid organs including spleen and many lymph nodes. Naïve $\mathrm{T}$ cells become activated by antigens presented by DC in lymphoid sites, resulting in $\mathrm{T}$ cell proliferation and differentiation to effector cells which can migrate to diverse tissues sites of pathogen encounter. Different types of effector $\mathrm{T}$ cells mediate diverse functions including enhancing inflammatory responses, mediating direct cellular cytotoxicity against virally infected cells or tumor cells, or helping B cells differentiate to antibody-secreting cells, and class switching of different antibody isotypes. The majority of antibody responses to protein antigens, viral and bacterial pathogens require $\mathrm{T}$ cell help; however, there are two types of $\mathrm{B}$ cells responses that occur independent of $\mathrm{T}$ cells. Certain types of antigens such as repeating polysaccharides within bacterial cell walls can directly crosslink the BCR and activate B cells, and have been referred to "thymus-independent antigens". In addition, "natural" antibodies that form part of the innate immune response, also can be generated in the absence of $\mathrm{T}$ cells ${ }^{2}$. Aside from these exceptions, $\mathrm{T}$ cells are essential for most aspects of adaptive immunity, and because the innate immune response itself cannot effectively clear most pathogens, life without $\mathrm{T}$ cells is not sustainable.

The role of the thymus in the development and function of $\mathrm{T}$ cells a highly regulated process within the tissue; specific differentiation and events occur in cortical and medullary regions ${ }^{3}$, 
and are regulated with age. The thymus structure comprises specialized stromal cells designated thymic epithelial cells (TECs) consisting of two major subsets: cortical and medullary thymic epithelial cells (cTEC and mTEC respectively), that govern both positive and negative selection of $\mathrm{T}$ cells; the localization and interaction of developing thymocytes with TEC subsets is critical for proper T cell export ${ }^{4}$. In addition, thymic output is also highly regulated by age and life stage; thymic-dependent production of $\mathrm{T}$ cells is critical during fetal development and early life, but is dispensable thereafter and wanes during early adulthood. Infants born lacking proper development of a thymus (due to DiGeorge syndrome or FoxN1 mutations) suffer from life threatening infections resulting in early mortality during the first year of life, due to reduced numbers and impaired function of peripheral $\mathrm{T}$ cells ${ }^{5-7}$. Thymus transplantation during early life can establish normal $\mathrm{T}$ cell numbers and function and enable these individuals to survive and thrive $e^{5,6,8}$. By contrast, thymectomy during infancy and early childhood typically is performed during cardiac surgery for repair of congenital abnormalities, does not compromise peripheral $\mathrm{T}$ cell functions and immune responses ${ }^{9,10}$, as infants are born with a full $\mathrm{T}$ cell complement in the periphery. In addition, there are multiple peripheral mechanisms for maintaining $\mathrm{T}$ cell numbers which have been partly elucidated in mice and are just beginning to be understood in humans.

In this review, we will discuss how the complex structure of thymus provides a unique microenvironment to orchestrate the differentiation of thymocytes and TEC, and educates $\mathrm{T}$ cells to recognize self from non-self. We will review how $\mathrm{T}$ cell development occurs in the thymus and the developmental checkpoints that thymocytes progress through to become mature $\mathrm{T}$ cells exported to the periphery. We will also discuss age-related regulation of thymic function based on results from mouse and human studies, and implications for immunosenescence and regulation.

\section{Thymic structure and development}

The development of thymic epithelial cells (TEC) are critical for thymic organogenesis which occurs during fetal development. Studies using mouse embryos have elucidated several factors intrinsic to TECs that play crucial roles in the development of thymic structure both pre-natally and post-natally ${ }^{3,11}$. The transcription factor FoxN1 is critical for all TEC development and maintenance (fetal and postnatal); loss of FoxN1 lead to loss of thymic structure and autoimmune disease in both humans and mice ${ }^{12-17}$ FoxN1 is highly expressed by embryonic thymic epithelial cells and at least $50 \%$ of postnatal TECs retain FoxN1 expression, highlighting its importance ${ }^{18}$. The regulation of FoxN1 expression in TEC is not fully understood although signaling pathways such as the bone morphogenetic protein (BMP) and wingless/integrated (wnt) factors have been described ${ }^{19,20}$. Considerably less is known about the regulation of FoxN1 in humans, and its role in maintaining thymus integrity.

The proper development of thymus tissue requires the generation of structurally and functionally distinct cortical and medullary regions via development of cTECs and mTECs, respectively. Early fetal TECs are bipotent, giving rise to both cortical and medullary epithelial cells (cTEC and mTECs, respectively) ${ }^{12,21,22}$. After homing to the thymic structure, the differentiation of cTECs and mTECs is perpetuated by additional mechanisms 
unique to each cortical or medullary epithelial cell lineage. The cTEC and mTEC lineages exhibit distinct expression of specific markers; cTECs can be identified by surface expression of Cytokeratin 8, Ly51 and CD205 while mTECs express cytokeratin 5, CD80 and UEA $1^{23}$. Although these markers identify the specific TEC lineage, expression of these factors varies within each subset, which may reflect maturation stages ${ }^{3,24}$. Recent studies on transcriptome profiling of murine TECs on the single cell level revealed that cellular heterogeneity of TECs may be reflection of the developmental stage of TECs ${ }^{25}$.

Another key transcription factor important in TEC function, designated autoimmune regulator (AIRE) protein is specifically expressed by mTECs and functions to induce promiscuous expression of tissue-restricted antigens (TRA) such as insulin (pancreasspecific) and kidney-specific proteins ${ }^{26-3026,27,31}$. The presentation of TRA by mTECS is one of the key mechanisms that leads to deletion of self-or auto-reactive T cells in the thymus establish central tolerance. AIRE deficiency leads to robust autoimmunity in both humans and mice ${ }^{32,33}$. In humans, AIRE dysfunction leads to a rare disorder called autoimmune poly endocrinopathy-candidiasis-ectodermal dystrophy (APECED) ${ }^{26}$, characterized by multi-endocrine autoimmune disease, chronic mucocutanous candidiasis and dystrophy of dental enamel and nails ${ }^{34}$. More than 40 mutations in the AIRE gene that leads to dysfunctional protein have been identified to cause this autosomal recessive inherited disease $\mathrm{e}^{34}$. Together, the TEC-specific factors are not only crucial for thymic structural integrity, but also play key roles in the promoting the development and selection of thymocytes as described below.

\section{T cell development in the thymus}

The earliest stage for $\mathrm{T}$ cell development originates in the bone marrow (BM) as hematopoietic stem cells (HSC) which are self-renewing and can differentiate into both myeloid and lymphoid progenitors; the latter give rise to both $\mathrm{T}$ and B-lymphocytes. Lymphoid progenitors circulate out of the bone marrow and those expressing platelet $(\mathrm{P})$ selected glycoprotein ligand 1(PSGL1) will enter the thymus via their interaction with Pselectin on thymic endothelial cells. Additional thymus homing signals are received via chemokines binding to CCR7 and CCR9 on the progenitor cells ${ }^{35-37}$. This thymus homing step is the earliest step in the development of functional $\mathrm{T}$ cells that is described below and diagrammed in Figure 1.

The migration of thymocytes within the thymic microenvironment directs their proper development ${ }^{38,39}$. Thymocytes are guided by various chemokines secreted by stromal cells including cTECS and mTECs that govern their movement from medullary to the cortical region and back to medullary region within the thymus before egress to the periphery (Figure 1). Beginning in the cortical-medullary junction, BM derived lymphoid progenitors first commit to the T cell lineage by receiving notch ligands (DLL4) and IL-7 provided by cTECs to become early thymic precursors (ETP $)^{40,41}$, also designated as "double negative" thymocytes for their lack of expression of CD4 and CD8 co-receptors which are markers of mature T cells. DN1/ETPs proceed on to migrate toward the subcapsular cortical region, triggering their development into DN2 and DN3 stages where they begin to rearrange the $T R B$ locus ${ }^{42,43}$, and express CD25/CD44 (Figure 1). Maturation to the DN3 stage involves 
a $\beta$-selection checkpoint where thymocytes progress onto the next developmental stage only when they are successful in generating an in frame TCR $\beta$ chain rearrangement. The rearranged TCR $\beta$ chain is paired with a pre-TCRa chain and tested for its ability to form a cell surface pre-TCR complex ${ }^{44}$. Successful expression of the pre-TCR complex initiates the proliferation and differentiation from DN3 to DN4 and to "Double positive" $\left(\mathrm{CD}^{+} \mathrm{CD}^{+}\right)$thymocytes characterized by co-expression of both co-receptors ${ }^{45,46}$. These DP cells form the majority of thymocytes in the thymus during early life ${ }^{47}$.

Formation of DP thymocytes is a key step in T cell development, as it is this stage which undergoes final maturation and selection for potential export to the periphery. The mature TCR complex is formed during this DP stage following TRA rearrangement, expression of a functional TCR a chain and association with the TCR $\beta$ chain and CD3 signaling molecules. DP thymocytes expressing mature TCR subsequently undergo positive selection for recognition of peptides in the context of self major histocompatibility complex (MHC). Through this process, low avidity recognition of self peptide: self MHC on cTECs by the TCR complex leads to a positive signal for survival (such as Bcl-2) while no recognition leads to death by neglect ${ }^{48}$. The recognition of self peptide: self MHC is also in part governed by the co-receptors CD4 and CD8 promoting lineage choice to be "single positive" (SP) cells expressing either the CD4 or CD8 coreceptor ${ }^{49}$ (Figure 1). These newly generated SP T cells are still not ready for export, as they require another selection event to screen for self-reactive $\mathrm{T}$ cells.

Following positive selection, SP T cells increase their expression of CCR7 and migrate to the medullary region via CCL19 and CCL21 produced by mTECs ${ }^{42,43}$. In the medulla, SP $\mathrm{CD}^{+}$and $\mathrm{SP} \mathrm{CD} 8^{+} \mathrm{T}$ cells undergo a process called negative selection, whereby selfreactive $\mathrm{T}$ cells are deleted, establishing central tolerance. During negative selection SP T cells are presented TRAs by mTECs and tested for their affinity towards self-antigen ${ }^{29}$. Strong recognition of self-peptide will lead to apoptosis mediated by Bim pro-apoptotic molecule and deletion of self-reactive $\mathrm{T}$ cells before they can migrate to the periphery and potentially trigger autoimmunity ${ }^{50,51}$. Together, these studies show that the thymic structure is highly organized with distinct cortical and medullary compartments to facilitate the proper development and selection of $\mathrm{T}$ cells with the ability to protect, but not generate selfreactivity.

The thymic selection events described above are quite stringent; the majority ( $>95 \%)$ of developing T cells "fail" positive or negative selection and die or fail to be exported. However, a full complement of naïve $\mathrm{CD} 4^{+}$and $\mathrm{CD}^{+} \mathrm{T}$ cells emerge following this rigorous selection, which collectively express a diverse array of TCR with the potential to recognize millions of different antigenic epitopes. Naïve $\mathrm{CD} 4^{+} \mathrm{T}$ cells recognizing epitopes presented by MHC class II molecules can be activated and differentiate to T-helper effector cells for coordinating all aspects of cellular immunity to diverse pathogens; naïve $\mathrm{CD} 8^{+} \mathrm{T}$ cells recognizing epitopes presented by MHC Class I molecules differentiate into cytotoxic $\mathrm{T}$ cells important for anti-viral and anti-tumor immunity. A third type of $\mathrm{T}$ cell lineage, designated regulatory $\mathrm{T}$ cells (Tregs) also develops in the thymus as a result of the same selection events. Tregs are distinguished by their expression of the Foxp3 transcription factor and are required in the periphery for proper immunoregulation and prevention of 
autoimmunity ${ }^{52}$. Interestingly, Tregs experience stronger positive selection signals and are more self-reactive than other conventional $\mathrm{T}$ cells ${ }^{53}$, and therefore result from a third decision point in the selection process. Tregs also express diverse TCR, but are distinct from the TCR expressed by conventional naïve $\mathrm{CD} 4^{+} \mathrm{T}$ cell counterparts ${ }^{54}$.

In addition to mature T cells with diverse TCR, a type of "innate"-like T cell called Natural killer T (NKT) cells also develop in the thymus. NKT cells are designated as innate T cells because they respond rapidly (minutes to hours) following stimulation and exhibit a limited TCR repertoire (and therefore limited specificity) with the majority of NKT cells expressing a common alpha chain, Va24 in human and Va14 in mice paired with Ja18 ${ }^{55}$. NKT cells also undergo positive selection at the DP thymocytes stage in the thymus but are selected by other DP thymocytes presenting endogenous glycolipids on CD1d molecules. NKT cells experience stronger TCR signal during positive selection and express PLZF, a transcriptional factor that commits NKT cells to their lineage ${ }^{53,56}$. Although NKT cells share a common progenitor stage (DP) as conventional T cells, they have distinct transcriptional programs that direct their commitment to NKT cells upon positive selection ${ }^{57,58}$. Several transcription factors have been identified that regulates the positive selection of NKT cells but not conventional T cells at the DP thymocyte stage ${ }^{57}$. NKT cells have diverse effector functions with cytotoxic capacity and both pro and anti-inflammatory cytokine production, and are potential targets for immunotherapies in cancer and autoimmunity ${ }^{59}$. The thymus therefore serves a key role in promoting and directing the development and selection of multiple types of T lymphocytes with specific functional roles in immune responses.

\section{Thymic involution and aging}

Much of our knowledge about thymus integrity and thymopoesis derives from studies in mice, which have been essential in revealing the molecular mechanisms underlying these processes. Human studies have provided new insights into the key differences between mice and human in this regard. Mice are born lymphopenic and have a small thymus that grows in size before it involutes with age. Unlike mice, humans are born with a full complement of $\mathrm{T}$ cells in circulation and lymphoid tissues and the human thymus is largest at birth and is most active up until puberty. After puberty, the thymus starts to involute with age and turns into fatty tissue ${ }^{60}$. The timing requirement for thymic output in immunoregulation also differs in mice and humans. Neonatal thymectomy in mice can give rise to lethal autoimmunity marked by multi-organ infiltrates which has been shown to occur due to a lack of Treg maturation ${ }^{61,62}$. By contrast, neonatal thymectomy in humans that has been performed during infant cardiac surgery, is not associated with autoimmunity later in life and individuals develop and maintain normal frequencies of Tregs in peripheral blood ${ }^{63,64}$. Similarly, individuals who experienced neonatal thymectomy (and are now in their third to fourth decade of life) do not exhibit increased susceptibility to infections during the critical window of childhood ${ }^{65}$. Together, these results indicate that the certain key events in thymus-dependent $\mathrm{T}$ cell development and the contribution of thymic output to establishing $\mathrm{T}$ cell homeostasis is largely set pre-natally and during the early post-natal period in humans. 
Despite the lack of overt immune dysregulation within individuals thymectomized in early life, there are several caveats that should be taken into consideration in evaluating these data. First, mediastinal extraction of the thymus during cardiac surgery may not remove all thymus tissue, as thymic remnants may extend into cervical regions 66,67 , and could mediate partial thymic function. In addition, the peripheral $\mathrm{T}$ cell compartment, including $\mathrm{T}$ cell numbers early after thymectomy and the proportion of naïve and memory T cells, is altered in thymectomized individuals compared to individuals with an intact thymus. There is an early reduction in $\mathrm{T}$ cell numbers after thymectomy and several studies have reported an accelerated accumulation of memory $\mathrm{T}$ cells in thymectomized compared to control individuals ${ }^{10,68-70}$, indicating that thymic output later in life is important for replenishing naïve $T$ cells and maintaining the ability to respond to new pathogens. Notably, thymectomized populations are living in the modern era, with advanced hygiene and low pathogen load, and also have generally received childhood vaccinations. Therefore, the lack of naïve $\mathrm{T}$ cells later in life may not have the same consequences in an environment of high pathogen load.

During normal human aging, the thymus continues its active process of thymopoiesis into the fourth decade of life manifested by the presence of active thymic tissue with DP thymocytes, which are greatly reduced after $40 \mathrm{yrs}$ of age $\mathrm{e}^{71}$. Thymic output can also be measured by assessing the presence of $\mathrm{T}$ cell receptor excision circles (TRECs) in naïve $\mathrm{T}$ cells marking recent thymic emigrants (RTEs) in both mice and human ${ }^{72}$. These studies show that with age, the presence of TRECs also decline, with a precipitous decrease after age 40 , indicating lower thymic output in humans ${ }^{73,74}$ In contrast, mice at 2 years of age is fully capable of generating recent thymic emigrants, indicating that mice thymic output is independent of age related thymic size ${ }^{75}$. Direct comparison studies showed that in humans the naïve $\mathrm{T}$ cell compartment is largely maintained by homeostatic turnover in the periphery and not by thymic output while thymic output maintains $\mathrm{T}$ cells numbers throughout the much shorter mouse lifetime ${ }^{72}$. These peripheral mechanisms involve the action of homeostatic and T cell survival cytokines such as IL-7 and IL-15 and contact of T cells with cognate or non-cognate stimuli, as defined in mouse models. In humans, the molecular mechanisms underlying peripheral $\mathrm{T}$ cell turnover have not been elucidated; however, recent evidence suggests that lymph nodes may create a tissue reservoir for long-term maintenance of naïve and resting $\mathrm{T}$ cells ${ }^{76,77}$.

The thymus atrophies with age in both mice and humans; however, mechanisms driving thymic involution are still not fully understood ${ }^{78,79}$. In mouse models and humans, the loss of TECs appears to be primarily associated with thymic atrophy and reductions in thymopoiesis, with several factors playing important roles in this process. The expression of the key TEC transcription factor, FoxN1 decreases with age causing rapid degradation of TECs, while forced expressed of FoxN1 reversed thymic degradation ${ }^{13,17}$. Moreover, expression of thymopoeisis-promoting factors such as IL-7 and MHC-II is also reduced in TECs with age ${ }^{80-82}$. Loss of either factors will inhibit the ability of TECs to interact and provide growth factors to developing thymocytes, thereby inhibiting thymopoiesis. With increasing age, TECs do not readily regenerate leading to hypostromal structure, enabling fat cells to accumulate and fill the thymic space in humans ${ }^{83,84}$. Cell ablation studies in mouse models suggest that cTEC may exhibit regeneration capacities during aging ${ }^{85}$, suggesting 
that therapeutic targeting of this subset could be a promising area for boosting thymic activity.

Sex hormones may also play an important role in thymic regeneration. Thymic involution occurs at a faster rate in males than females suggesting a role for androgens in thymic atrophy 86,87 . Consistent with this idea, gonadal steroid hormones have shown to negatively impact TEC survival, and conversely, sex steroid ablation therapy (SSA) leads to an increase in thymus size and thymocyte development ${ }^{86,88,89}$. Together, the reduction in epithelial cell turnover and expression of key TEC-associated transcription factors coupled with age- and sex-related effects on thymic structural integrity and increased fat accumulation result in reduced homing of bone marrow progenitors and induction of thymopoiesis.

\section{Concluding remarks}

The thymus provides a specialized microenvironment for the development of highly diverse and functional $\mathrm{T}$ cells that are also tolerant to self. Thymopoiesis is spatially regulated within the thymus with distinct checkpoints occurring as thymocytes progress through their developmental stages from the cortical-medullary region to the cortex where cTECs mediate positive selection. Upon positive selection, SP thymocytes migrate to the medulla where mTECs govern negative selection to delete autoreactive $\mathrm{T}$ cells, establish central tolerance. Thymopoiesis results in a full complement of peripheral naïve $\mathrm{T}$ cells with diverse recognition capacity against diverse pathogens and subsets of regulatory $\mathrm{T}$ cells to inhibit overactive immune responses and autoimmunity. This highly regulated process is quite active at birth in humans; however, thymic involution associated with reduced TEC content and integrity begins during early childhood and continues through adulthood, resulting in a loss of thymic structural integrity and cessation of thymopoiesis that occurs well before the natural end of the human lifespan. Remarkably, much of the functional and regulatory aspects of thymus-dependent $\mathrm{T}$ cell responses occur early in life and may be largely dispensable thereafter; multiple peripheral mechanisms for homeostasis maintain $\mathrm{T}$ cell numbers and proper immunoregulation. Targeting thymic regeneration and modulation of thymic output can nevertheless be therapeutic for boosting production of new naïve $\mathrm{T}$ cells in vaccines and promoting human $\mathrm{T}$ cell reconstitution after treatments that severely depletes $\mathrm{T}$ cells, such as in bone marrow transplantation, chemotherapy and following severe viral infections. A greater understanding of these processes in human thymic tissue will be important for translating findings from mice to humans and revealing mechanisms underlying the complexity of the human thymus.

\section{References:}

1. Brubaker SW, Bonham KS, Zanoni I, Kagan JC. Innate Immune Pattern Recognition: A Cell Biological Perspective. Annual Review of Immunology. 2015;33(1):257-290.

2. Kaveri SV, Silverman GJ, Bayry J. Natural IgM in immune equilibrium and harnessing their therapeutic potential. J Immunol. 2012;188(3):939-945. [PubMed: 22262757]

3. Takahama Y, Ohigashi I, Baik S, Anderson G. Generation of diversity in thymic epithelial cells. Nat Rev Immunol. 2017;17(5):295-305. [PubMed: 28317923]

4. Shores EW, Van Ewijk W, Singer A. Disorganization and restoration of thymic medullary epithelial cells in T cell receptor-negative scid mice: evidence that receptor-bearing lymphocytes influence 
maturation of the thymic microenvironment. Eur J Immunol. 1991;21(7):1657-1661. [PubMed: 2060577]

5. Markert ML, Sarzotti M, Ozaki DA, et al. Thymus transplantation in complete DiGeorge syndrome: immunologic and safety evaluations in 12 patients. Blood. 2003;102(3):1121-1130. [PubMed: 12702512]

6. Chinn IK, Milner JD, Scheinberg P, Douek DC, Markert ML. Thymus transplantation restores the repertoires of forkhead box protein 3 (FoxP3)+ and FoxP3-T cells in complete DiGeorge anomaly. Clin Exp Immunol. 2013;173(1):140-149. [PubMed: 23607606]

7. Amorosi S, D'Armiento M, Calcagno G, et al. FOXN1 homozygous mutation associated with anencephaly and severe neural tube defect in human athymic Nude/SCID fetus. Clin Genet. 2008;73(4):380-384. [PubMed: 18339010]

8. Markert ML, Marques JG, Neven B, et al. First use of thymus transplantation therapy for FOXN1 deficiency (nude/SCID): a report of 2 cases. Blood. 2011;117(2):688-696. [PubMed: 20978268]

9. Roosen J, Oosterlinck W, Meyns B. Routine thymectomy in congenital cardiac surgery changes adaptive immunity without clinical relevance. Interact Cardiovasc Thorac Surg. 2015;20(1):101106. [PubMed: 25320142]

10. Sauce D, Appay V. Altered thymic activity in early life: how does it affect the immune system in young adults? Curr Opin Immunol. 2011;23(4):543-548. [PubMed: 21752618]

11. Abramson J, Anderson G. Thymic Epithelial Cells. Annu Rev Immunol. 2017;35:85-118. [PubMed: 28226225]

12. Bleul CC, Corbeaux T, Reuter A, Fisch P, Monting JS, Boehm T. Formation of a functional thymus initiated by a postnatal epithelial progenitor cell. Nature. 2006;441(7096):992-996. [PubMed: 16791198]

13. Chen L, Xiao S, Manley NR. Foxn1 is required to maintain the postnatal thymic microenvironment in a dosage-sensitive manner. Blood. 2009;113(3):567-574. [PubMed: 18978204]

14. Corbeaux T, Hess I, Swann JB, Kanzler B, Haas-Assenbaum A, Boehm T. Thymopoiesis in mice depends on a Foxn1-positive thymic epithelial cell lineage. Proc Natl Acad Sci U S A. 2010;107(38):16613-16618. [PubMed: 20823228]

15. Cheng L, Guo J, Sun L, et al. Postnatal tissue-specific disruption of transcription factor FoxN1 triggers acute thymic atrophy. J Biol Chem. 2010;285(8):5836-5847. [PubMed: 19955175]

16. Zuklys S, Handel A, Zhanybekova S, et al. Foxn1 regulates key target genes essential for T cell development in postnatal thymic epithelial cells. Nat Immunol. 2016;17(10):1206-1215. [PubMed: 27548434]

17. Xu M, Sizova O, Wang L, Su DM. A Fine-Tune Role of Mir-125a-5p on Foxn1 During AgeAssociated Changes in the Thymus. Aging Dis. 2017;8(3):277-286. [PubMed: 28580184]

18. Rode I, Martins VC, Kublbeck G, Maltry N, Tessmer C, Rodewald HR. Foxn1 Protein Expression in the Developing, Aging, and Regenerating Thymus. J Immunol. 2015;195(12):5678-5687. [PubMed: 26538393]

19. Bleul CC, Boehm T. BMP signaling is required for normal thymus development. J Immunol. 2005;175(8):5213-5221. [PubMed: 16210626]

20. Balciunaite G, Keller MP, Balciunaite E, et al. Wnt glycoproteins regulate the expression of FoxN1, the gene defective in nude mice. Nat Immunol. 2002;3(11):1102-1108. [PubMed: 12379851]

21. Kingston R, Jenkinson EJ, Owen JJ. A single stem cell can recolonize an embryonic thymus, producing phenotypically distinct T-cell populations. Nature. 1985;317(6040):811-813. [PubMed: 3877245]

22. Rodewald HR, Paul S, Haller C, Bluethmann H, Blum C. Thymus medulla consisting of epithelial islets each derived from a single progenitor. Nature. 2001;414(6865):763-768. [PubMed: 11742403]

23. Rossi SW, Jeker LT, Ueno T, et al. Keratinocyte growth factor (KGF) enhances postnatal T-cell development via enhancements in proliferation and function of thymic epithelial cells. Blood. 2007;109(9):3803-3811. [PubMed: 17213286] 
24. Alexandropoulos K, Danzl NM. Thymic epithelial cells: antigen presenting cells that regulate T cell repertoire and tolerance development. Immunol Res. 2012;54(1-3):177-190. [PubMed: 22454100]

25. Kernfeld EM, Genga RMJ, Neherin K, Magaletta ME, Xu P, Maehr R. A Single-Cell Transcriptomic Atlas of Thymus Organogenesis Resolves Cell Types and Developmental Maturation. Immunity. 2018;48(6):1258-1270 e1256. [PubMed: 29884461]

26. Liston A, Gray DH, Lesage S, et al. Gene dosage--limiting role of Aire in thymic expression, clonal deletion, and organ-specific autoimmunity. J Exp Med. 2004;200(8):1015-1026. [PubMed: 15492124]

27. Anderson MS, Venanzi ES, Chen Z, Berzins SP, Benoist C, Mathis D. The cellular mechanism of Aire control of T cell tolerance. Immunity. 2005;23(2):227-239. [PubMed: 16111640]

28. Gray D, Abramson J, Benoist C, Mathis D. Proliferative arrest and rapid turnover of thymic epithelial cells expressing Aire. J Exp Med. 2007;204(11):2521-2528. [PubMed: 17908938]

29. Irla M, Hugues S, Gill J, et al. Autoantigen-specific interactions with CD4+ thymocytes control mature medullary thymic epithelial cell cellularity. Immunity. 2008;29(3):451-463. [PubMed: 18799151]

30. Hansenne I, Louis C, Martens H, et al. Aire and Foxp3 expression in a particular microenvironment for T cell differentiation. Neuroimmunomodulation. 2009;16(1):35-44. [PubMed: 19077444]

31. Liston A, Lesage S, Wilson J, Peltonen L, Goodnow CC. Aire regulates negative selection of organ-specific T cells. Nat Immunol. 2003;4(4):350-354. [PubMed: 12612579]

32. Kisand K, Peterson P. Autoimmune polyendocrinopathy candidiasis ectodermal dystrophy: known and novel aspects of the syndrome. Ann N Y Acad Sci. 2011;1246:77-91. [PubMed: 22236432]

33. Peterson P, Org T, Rebane A. Transcriptional regulation by AIRE: molecular mechanisms of central tolerance. Nat Rev Immunol. 2008;8(12):948-957. [PubMed: 19008896]

34. Ahonen P, Myllärniemi S, Sipilä I, Perheentupa J. Clinical Variation of Autoimmune Polyendocrinopathy-Candidiasis-Ectodermal Dystrophy (APECED) in a Series of 68 Patients. New England Journal of Medicine. 1990;322(26):1829-1836. [PubMed: 2348835]

35. Rossi FM, Corbel SY, Merzaban JS, et al. Recruitment of adult thymic progenitors is regulated by P-selectin and its ligand PSGL-1. Nat Immunol. 2005;6(6):626-634. [PubMed: 15880112]

36. Krueger A, Willenzon S, Lyszkiewicz M, Kremmer E, Forster R. CC chemokine receptor 7 and 9 double-deficient hematopoietic progenitors are severely impaired in seeding the adult thymus. Blood. 2010;115(10):1906-1912. [PubMed: 20040757]

37. Zlotoff DA, Sambandam A, Logan TD, Bell JJ, Schwarz BA, Bhandoola A. CCR7 and CCR9 together recruit hematopoietic progenitors to the adult thymus. Blood. 2010;115(10):1897-1905. [PubMed: 19965655]

38. Lind EF, Prockop SE, Porritt HE, Petrie HT. Mapping precursor movement through the postnatal thymus reveals specific microenvironments supporting defined stages of early lymphoid development. J Exp Med. 2001;194(2):127-134. [PubMed: 11457887]

39. Takahama Y Journey through the thymus: stromal guides for T-cell development and selection. Nat Rev Immunol. 2006;6(2):127-135. [PubMed: 16491137]

40. Radtke F, Wilson A, Stark G, et al. Deficient T cell fate specification in mice with an induced inactivation of Notch1. Immunity. 1999;10(5):547-558. [PubMed: 10367900]

41. Peschon JJ, Morrissey PJ, Grabstein KH, et al. Early lymphocyte expansion is severely impaired in interleukin 7 receptor-deficient mice. J Exp Med. 1994;180(5):1955-1960. [PubMed: 7964471]

42. Ueno T, Saito F, Gray DH, et al. CCR7 signals are essential for cortex-medulla migration of developing thymocytes. J Exp Med. 2004;200(4):493-505. [PubMed: 15302902]

43. Kurobe H, Liu C, Ueno T, et al. CCR7-dependent cortex-to-medulla migration of positively selected thymocytes is essential for establishing central tolerance. Immunity. 2006;24(2):165-177. [PubMed: 16473829]

44. Krangel MS. Mechanics of T cell receptor gene rearrangement. Curr Opin Immunol. 2009;21(2): 133-139. [PubMed: 19362456]

45. Gascoigne NRJ, Rybakin V, Acuto O, Brzostek J. TCR Signal Strength and T Cell Development. Annual Review of Cell and Developmental Biology. 2016;32(1):327-348. 
46. Fehling HJ, Krotkova A, Saint-Ruf C, von Boehmer H. Crucial role of the pre-T-cell receptor alpha gene in development of alpha beta but not gamma delta T cells. Nature. 1995;375(6534):795-798. [PubMed: 7596413]

47. Cuddihy AR, Ge S, Zhu J, et al. VEGF-mediated cross-talk within the neonatal murine thymus. Blood. 2009;113(12):2723. [PubMed: 19088378]

48. McKean DJ, Huntoon CJ, Bell MP, et al. Maturation versus death of developing double-positive thymocytes reflects competing effects on Bcl-2 expression and can be regulated by the intensity of CD28 costimulation. J Immunol. 2001;166(5):3468-3475. [PubMed: 11207305]

49. Bhandoola A, Cibotti R, Punt JA, et al. Positive Selection as a Developmental Progression Initiated by a $\beta T C R$ Signals that Fix TCR Specificity prior to Lineage Commitment. Immunity. 1999;10(3): 301-311. [PubMed: 10204486]

50. Sohn SJ, Thompson J, Winoto A. Apoptosis during negative selection of autoreactive thymocytes. Curr Opin Immunol. 2007;19(5):510-515. [PubMed: 17656079]

51. Bouillet P, Purton JF, Godfrey DI, et al. BH3-only Bcl-2 family member Bim is required for apoptosis of autoreactive thymocytes. Nature. 2002;415(6874):922-926. [PubMed: 11859372]

52. Ziegler SF. FOXP3: of mice and men. Annu Rev Immunol. 2006;24:209-226. [PubMed: 16551248]

53. Moran AE, Holzapfel KL, Xing Y, et al. T cell receptor signal strength in Treg and iNKT cell development demonstrated by a novel fluorescent reporter mouse. J Exp Med. 2011;208(6):12791289. [PubMed: 21606508]

54. Golding A, Darko S, Wylie WH, Douek DC, Shevach EM. Deep sequencing of the TCR-beta repertoire of human forkhead box protein $3($ FoxP3)(+) and FoxP3(-) T cells suggests that they are completely distinct and non-overlapping. Clin Exp Immunol. 2017;188(1):12-21. [PubMed: 27880974]

55. Das R, Sant'Angelo DB, Nichols KE. Transcriptional control of invariant NKT cell development. Immunol Rev. 2010;238(1):195-215. [PubMed: 20969594]

56. Seiler MP, Mathew R, Liszewski MK, et al. Elevated and sustained expression of the transcription factors Egr1 and Egr2 controls NKT lineage differentiation in response to TCR signaling. Nat Immunol. 2012;13(3):264-271. [PubMed: 22306690]

57. Thapa P, Das J, McWilliams D, et al. The transcriptional repressor NKAP is required for the development of iNKT cells. Nature Communications. 2013;4:1582.

58. Kim EY, Lynch L, Brennan PJ, Cohen NR, Brenner MB. The transcriptional programs of iNKT cells. Semin Immunol. 2015;27(1):26-32. [PubMed: 25841627]

59. Wu L, Gabriel CL, Parekh VV, Van Kaer L. Invariant natural killer T cells: innate-like T cells with potent immunomodulatory activities. Tissue Antigens. 2009;73(6):535-545. [PubMed: 19392798]

60. Haynes BF, Markert ML, Sempowski GD, Patel DD, Hale LP. The role of the thymus in immune reconstitution in aging, bone marrow transplantation, and HIV-1 infection. Annu Rev Immunol. 2000;18:529-560. [PubMed: 10837068]

61. Asano M, Toda M, Sakaguchi N, Sakaguchi S. Autoimmune disease as a consequence of developmental abnormality of a T cell subpopulation. J Exp Med. 1996;184(2):387-396. [PubMed: 8760792]

62. Sakaguchi S, Takahashi T, Nishizuka Y. Study on cellular events in postthymectomy autoimmune oophoritis in mice. I. Requirement of Lyt-1 effector cells for oocytes damage after adoptive transfer. J Exp Med. 1982;156(6):1565-1576. [PubMed: 6983557]

63. Silva SL, Albuquerque AS, Serra-Caetano A, et al. Human naive regulatory T-cells feature high steady-state turnover and are maintained by IL-7. Oncotarget. 2016;7(11):12163-12175. [PubMed: 26910841]

64. Silva SL, Albuquerque A, Amaral AJ, et al. Autoimmunity and allergy control in adults submitted to complete thymectomy early in infancy. PLoS One. 2017;12(7):e0180385. [PubMed: 28686710]

65. Mancebo E, Clemente J, Sanchez J, et al. Longitudinal analysis of immune function in the first 3 years of life in thymectomized neonates during cardiac surgery. Clin Exp Immunol. 2008;154(3): 375-383. [PubMed: 18811694]

66. Yu L, Ma S, Jing Y, Zhang Y, Li F, Krasna MJ. Combined unilateral-thoracoscopic and mediastinoscopic thymectomy. Ann Thorac Surg. 2010;90(6):2068-2070. [PubMed: 21095376] 
67. Costa NS, Laor T, Donnelly LF. Superior cervical extension of the thymus: a normal finding that should not be mistaken for a mass. Radiology. 2010;256(1):238-242. [PubMed: 20505060]

68. van den Broek T, Delemarre EM, Janssen WJ, et al. Neonatal thymectomy reveals differentiation and plasticity within human naive T cells. J Clin Invest. 2016;126(3):1126-1136. [PubMed: 26901814]

69. Eysteinsdottir JH, Freysdottir J, Haraldsson A, et al. The influence of partial or total thymectomy during open heart surgery in infants on the immune function later in life. Clin Exp Immunol. 2004;136(2):349-355. [PubMed: 15086401]

70. Prelog M, Keller M, Geiger R, et al. Thymectomy in early childhood: significant alterations of the CD4(+)CD45RA(+)CD62L(+) T cell compartment in later life. Clin Immunol. 2009;130(2):123132. [PubMed: 18977182]

71. Thome JJ, Grinshpun B, Kumar BV, et al. Longterm maintenance of human naive T cells through in situ homeostasis in lymphoid tissue sites. Sci Immunol. 2016;1(6).

72. den Braber I, Mugwagwa T, Vrisekoop N, et al. Maintenance of peripheral naive T cells is sustained by thymus output in mice but not humans. Immunity. 2012;36(2):288-297. [PubMed: 22365666]

73. Nasi M, Troiano L, Lugli E, et al. Thymic output and functionality of the IL-7/IL-7 receptor system in centenarians: implications for the neolymphogenesis at the limit of human life. Aging Cell. 2006;5(2):167-175. [PubMed: 16626395]

74. Mitchell WA, Lang PO, Aspinall R. Tracing thymic output in older individuals. Clin Exp Immunol. 2010;161(3):497-503. [PubMed: 20646007]

75. Hale JS, Boursalian TE, Turk GL, Fink PJ. Thymic output in aged mice. Proc Natl Acad Sci U S A. 2006;103(22):8447-8452. [PubMed: 16717190]

76. Miron M, Kumar BV, Meng W, et al. Human Lymph Nodes Maintain TCF-1(hi) Memory T Cells with High Functional Potential and Clonal Diversity throughout Life. J Immunol. 2018.

77. Thome JJ, Grinshpun B, Kumar BV, et al. Longterm maintenance of human naive T cells through in situ homeostasis in lymphoid tissue sites. Sci Immunol. 2016;1(6):aah6506.

78. Lynch HE, Goldberg GL, Chidgey A, Van den Brink MRM, Boyd R, Sempowski GD. Thymic involution and immune reconstitution. Trends Immunol. 2009;30(7):366-373. [PubMed: 19540807]

79. Palmer DB. The Effect of Age on Thymic Function. Front Immunol. 2013;4.

80. Erickson M, Morkowski S, Lehar S, et al. Regulation of thymic epithelium by keratinocyte growth factor. Blood. 2002;100(9):3269-3278. [PubMed: 12384427]

81. Zamisch M, Moore-Scott B, Su DM, Lucas PJ, Manley N, Richie ER. Ontogeny and regulation of IL-7-expressing thymic epithelial cells. J Immunol. 2005;174(1):60-67. [PubMed: 15611228]

82. Ribeiro AR, Rodrigues PM, Meireles C, Di Santo JP, Alves NL. Thymocyte selection regulates the homeostasis of IL-7-expressing thymic cortical epithelial cells in vivo. J Immunol. 2013;191(3): 1200-1209. [PubMed: 23794633]

83. Yang H, Youm YH, Sun Y, et al. Axin expression in thymic stromal cells contributes to an agerelated increase in thymic adiposity and is associated with reduced thymopoiesis independently of ghrelin signaling. J Leukoc Biol. 2009;85(6):928-938. [PubMed: 19299626]

84. Gruver AL, Hudson LL, Sempowski GD. Immunosenescence of ageing. J Pathol. 2007;211(2): 144-156. [PubMed: 17200946]

85. Rode I, Boehm T. Regenerative capacity of adult cortical thymic epithelial cells. Proc Natl Acad Sci U S A. 2012;109(9):3463-3468. [PubMed: 22331880]

86. Olsen NJ, Olson G, Viselli SM, Gu X, Kovacs WJ. Androgen receptors in thymic epithelium modulate thymus size and thymocyte development. Endocrinology. 2001;142(3):1278-1283. [PubMed: 11181545]

87. Gui J, Morales AJ, Maxey SE, et al. MCL1 increases primitive thymocyte viability in female mice and promotes thymic expansion into adulthood. Int Immunol. 2011;23(10):647-659. [PubMed: 21937457]

88. Zoller AL, Kersh GJ. Estrogen induces thymic atrophy by eliminating early thymic progenitors and inhibiting proliferation of beta-selected thymocytes. J Immunol. 2006;176(12):7371-7378. [PubMed: 16751381] 
89. Sutherland JS, Goldberg GL, Hammett MV, et al. Activation of thymic regeneration in mice and humans following androgen blockade. J Immunol. 2005;175(4):2741-2753. [PubMed: 16081852] 


\section{KEY POINTS:}

- $\quad$ THE THYMUS IS A SPECIALIZED ORGAN THAT DIRECTS THE DEVELOPMENT AND SELECTION OF T CELLS WHICH DIRECT ADAPTIVE IMMUNITY.

- $\quad$ THYMIC FUNCTION IS SPATIALLY AND TEMPORALLY REGULATED AND WANES WITH AGE

- $\quad$ THYMIC OUTPUT IS ESSENTIAL DURING EARLY LIFE TO ESTABLISH IMMUNE COMPETENCE AND HOMEOSTASIS BUT IS DISPENSABLE THEREAFTER 


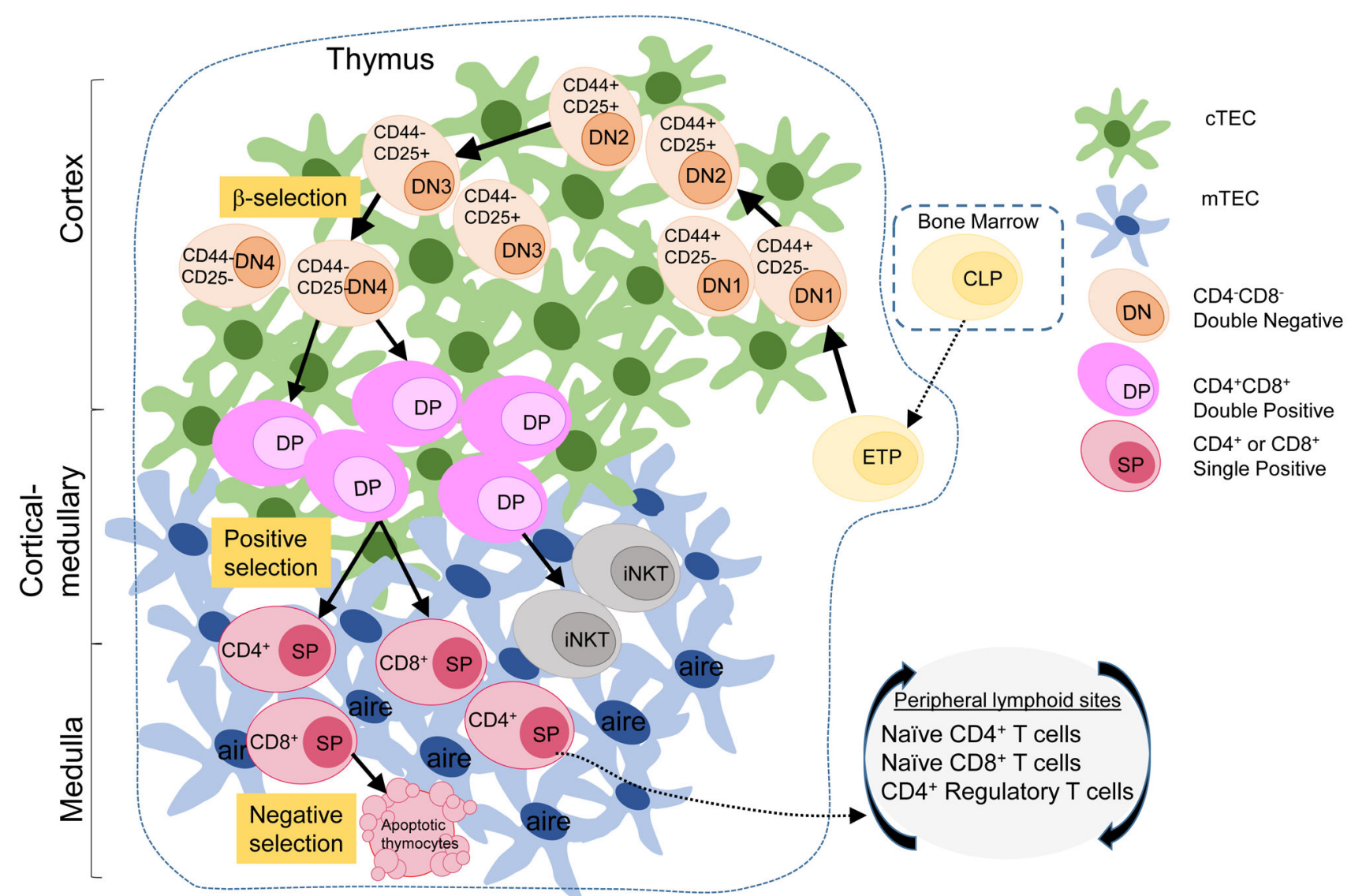

Figure 1: The development of $T$ cells in the thymus.

Bone marrow (BM)-derived lymphoid progenitor cells enter the thymus to begin commitment to the $\mathrm{T}$ cell lineage, becoming double negative 'DN' thymocytes (tan-orange) based on the lack of expression of CD4 and CD8 co-receptors. DN thymocytes progress through sequential DN1-4 stages, as defined by the coordinate expression of CD44 and CD25 on the cell surface. The T cell receptor (TCR) $\beta$-chain is expressed at DN3, triggering progression and maturation to double positive 'DP' thymocytes (pink) expressing both CD4 and CD8 co-receptors. Positive selection delineates selection of thymocytes into the CD4, Thelper, or CD8, cytotoxic T cell lineage to become single positive 'SP' CD4 or CD8 T cells (maroon). After positive selection, $\mathrm{SP} \mathrm{CD} 4^{+}$or $\mathrm{CD}^{+} \mathrm{T}$ cells migrate to the medulla to go through negative selection mediated by mTECs, where autoreactive SP T cells are deleted by apoptosis while SP T cells that pass negative selection are exported to the periphery. This process of thymopoiesis results in population of peripheral blood and lymphoid sites with naive $\mathrm{CD} 4^{+}$and $\mathrm{CD} 8^{+} \mathrm{T}$ cells and $\mathrm{CD} 4^{+}$regulatory $\mathrm{T}$ cells (Tregs). 